\title{
In Memory of Hegel, Philosopher among Toque Macaques
}

For the animal shall not be measured by man...

They are not brethren, they are not underlings;

they are other nations...

- Henry Beston, The Outermost House

In memory of Hegel, who scaled

the Buddha in his lifetime,

who twined his tail among the stone

tendrils and trunks of the hidden temple

his kind inherited and he held,

Hegel who found offerings sweet

as all the other flowers.

In memory of Hegel, philosopher

among toque macaques and leader

of his troop for more than five years, always kind to his mates, playful

and gentle with his many offspring,

Hegel of the black lips, quick

orange eyes and upswept hair,

the long-armed, short-legged lord

of ancient fig trees, thick vines,

and lagoons overgrown with lilies

for whose bulbs he dove and braved

the crocodile. In memory of Hegel,

friend of Jeeves, Hegel who is no

fable, his face in notebooks

and on video, immortal, documented,

Hegel for whom my eyes tear,

even when his Wild Asia footage

is rerun as a clip on Primary Emotions.

In memory of Hegel, who died when

monkey politics and show of teeth

met shrieking will to power:

Duci bit his face so deeply 
he went into shock, and although

Jeeves held him as he shivered, looked into his eyes and licked his golden face fur tenderly, in the end nothing could hold Hegel but the earth he curled into, not even love. The macaques come where he lies on the leaf-litter, one or two at a time, circle in memory of Hegel, and some wave the flies from the corpse to touch his forehead and cheek with their long, crooked fingers and press their faces to his. All but Duci, now the leader, who is rough with his mates and terrorizes the young, chasing them down to shake them, throw them, poke their genitals.

One morning three months later, Duci is found severely beaten, a swathe of skin ripped from his scalp: a field biologist says the females toppled his regime. They have chosen Jeeves to be the new father of their children and Hegel's, his nature or culture a force for change, still to be reckoned with, Hegel and the memory of Hegel, who was known to them by some other name, in a language of cry and call, posture and fur, gesturings of tail and hand. 